\title{
ZAANGAŻOWANIE UNII EUROPEJSKIEJ W ZAPEWNIANIE BEZPIECZEŃSTWA MIĘDZYNARODOWYCH MECZÓW PIŁKI NOŻNEJ: WSPÓŁPRACA POLICYJNA I WYMIANA INFORMACJI
}

\author{
Magdalena Dobrowolska-Opała \\ Wydział Dziennikarstwa i Nauk Politycznych, Uniwersytet Warszawski \\ e-mail: magdalenadobrowolska89@gmail.com
}

\begin{abstract}
Streszczenie: Celem artykułu są opis oraz analiza bazowych dokumentów związanych z bezpieczeństwem międzynarodowych meczów piłkarskich w ujęciu współpracy policyjnej i wymiany informacji za pośrednictwem narodowych punktów informacyjnych dla piłki nożnej (NFIP). Artykuł stanowi niepodejmowaną dotychczas próbę rozstrzygnięcia wyboru między obligatoryjnym a fakultatywnym charakterem regulacji w omawianym obszarze. Uwaga zostaje także skupiona na ewolucji podejmowanych zagadnień i rozwiązań dotyczących bezpieczeństwa i porządku publicznego w związku z meczami piłki nożnej.
\end{abstract}

Słowa kluczowe: bezpieczeństwo meczów piłki nożnej, podręczniki współpracy policyjnej, międzynarodowa współpraca sił policyjnych, narodowe punkty informacyjne dla piłki nożnej, Europejska konwencja w sprawie przemocy i ekscesów widzów w czasie imprez sportowych, a w szczególności meczów piłki nożnej

\section{WSTĘP}

Magię sportu i jej zbawienny wpływ na społeczeństwo dostrzegali już starożytni. Pokaz siły, sprytu i potęgi ludzkiej woli służył nie tylko celom religijnym, ale także zapewnieniu rozrywki społeczeństwu. Początkowo tylko wybranym jego członkom, poprzez stopniowe otwieranie się dla szerszych mas społecznych, aż do osiągnięcia niewyobrażalnego poziomu masowości, pozwalającego milionom osób śledzić sportowe wyczyny z dowolnego miejsca na świecie. Obok sportowych emocji, medialnego szumu i oszałamiających kwot pieniędzy znajdują się kwestie bezpieczeństwa. Często lekceważone, błędnie szacowane czy nawet niedostrzegane, mogą zamienić święto sportu w tragedię pociągającą za sobą wiele ludzkich istnień. W historii sportu było kilkanaście incydentów stanowiących dla 
współczesnych przestrogę, paradoksalnie zmieniających oblicze aren sportowych oraz wymuszających zmiany prawne i organizacyjne. Na gruncie europejskim organizacje o zasięgu międzynarodowym szybko dostrzegły potrzebę zajmowania się sportem i nieodłącznie mu towarzyszącymi wymogami bezpieczeństwa. Nie są to wyłącznie podmioty o charakterze stricte sportowym, nieoceniony wkład wnoszą bowiem organizacje, których priorytetowe cele nie dotyczą bezpośrednio (bądź wyłącznie) sportu.

Niniejsza praca koncentruje się na zaangażowaniu Unii Europejskiej w zapewnianie bezpieczeństwa międzynarodowych meczów piłki nożnej. Swoisty system, który wypracowały w tym obszarze Wspólnoty Europejskie, stanowi dowód międzynarodowej woli do regulacji i wzajemnego wsparcia w trakcie wielkoformatowych imprez masowych, jakimi są bez wątpienia międzynarodowe mecze piłki nożnej. Sama piłka nożna, jako sport mający wielomilionową rzeszę europejskich fanów, sprawia, że unijne regulacje nie mogły pominąć tego aspektu życia społecznego obywateli UE. Kluczowym pytaniem jest tutaj kwestia fakultatywności podejmowanych rozwiązań. Czy dobrowolny charakter aktywności państw członkowskich wpływa na korzyść kształtującego się systemu bezpieczeństwa międzynarodowych meczów piłki nożnej czy wręcz przeciwnie - blokuje konieczne zmiany i modyfikacje. Także widoczny brak spójności, przede wszystkim definicyjnej, wzbudza pewne kontrowersje, szczególnie w sytuacjach wymagających policyjnej współpracy między państwami. Aby odpowiedzieć na wskazane pytania, należy dokonać przeglądu podstawowych unijnych regulacji dotyczących międzynarodowych meczów piłki nożnej, włączając historyczne tło ich powstania oraz szczegółową analizę kamienia milowego wskazanej tematyki, tj. Europejską konwencję w sprawie przemocy i ekscesów widzów w czasie imprez sportowych, a w szczególności meczów piłki nożnej. Zestawienie ze sobą treści podręczników z rekomendacjami dla międzynarodowej współpracy policyjnej pomoże ponadto zrozumieć, jak kształtowały się i zmieniały obszary zainteresowania sił policyjnych państw członkowskich.

\section{EUROPEJSKA KONWENCJA W SPRAWIE PRZEMOCY I EKSCESÓW WIDZÓW W CZASIE IMPREZ SPORTOWYCH, A W SZCZEGÓLNOŚCI MECZÓW PIŁKI NOŻNEJ}

Europejską konwencję w sprawie przemocy i ekscesów widzów w czasie imprez sportowych, a w szczególności meczów piłki nożnej ${ }^{1}$ sporządzono 19 sierpnia 1985 roku w Strasburgu. Jako dorobek Rady Europy została ona zaimplementowana przez większość państw członkowskich, stając się z czasem także

1 Europejska konwencja w sprawie przemocy i ekscesów widzów w czasie imprez sportowych, a w szczególności meczów piłki nożnej, sporządzona w Strasburgu dnia 19 sierpnia 1985 r., Dz.U. 1995 nr 129 poz. 625, dalej jako Europejska konwencja lub EK. 
punktem wyjścia regulacji unijnych, wzorcem do uszczegółowienia konkretnych rozwiązań - także tych podejmowanych indywidualnie przez państwa. Tłem powstania Europejskiej konwencji były pogarszające się warunki techniczne stadionów oraz brak dostatecznej dbałości o bezpieczeństwo widzów. W samym tylko roku 1985, na kilka miesięcy przed sporządzeniem konwencji, Europą wstrząsnęły dwa wypadki. Pierwszy, z 11 maja, wydarzył się w angielskim mieście Bradford, położonym w hrabstwie West Yorkshire. W trakcie meczu między lokalną drużyną Bradford City Football Club a Lincoln City Football Club główna trybuna stadionu Valley Parade stanęła w płomieniach. Była to drewniana konstrukcja, przyczyną pożaru stał się prawdopodobnie niedopałek papierosa rzucony między siedzenia. Na niekorzyść zadziałała pogoda - porywisty wiatr spotęgował siłę płomieni, oraz przestarzała konstrukcja, szczególnie kołowroty przy wejściu na stadion. Na skutek poparzeń, paniki tłumu oraz uduszenia zmarło 56 osób, a 265 zostało rannych ${ }^{2}$. Przyczyną drugiego wypadku, z 29 maja, stały się zamieszki kibiców na brukselskim stadionie Heysel. Podobnie jak w przypadku Bradford, stadion należał do przestarzałych obiektów, jego stan techniczny wymagał natychmiastowych remontów, małe i ciasne sektory, pozbawione wyjść ewakuacyjnych, stanowiły ogromne zagrożenie dla ludzi. W trakcie walk między kibicami Juventusu i Liverpoolu część osób udusiła się, została przygnieciona przez betonową ścianę bądź zadeptana na śmierć. Łącznie zmarło 39 osób, a około 600 zostało rannych [Rowland 2011] . Wskazane powyżej przykłady ukazują, w jak fatalnym stanie znajdowała się część ówczesnych stadionów oraz jak bezmyślne decyzje podejmowano zarówno po stronie organizatora, jak i policji. Europejska konwencja miała to zmienić i wprowadzić zestaw dobrych praktyk przydatnych obu tym podmiotom. W historii bezpieczeństwa meczów piłki nożnej otworzył się nowy rozdział.

Już we wstępie do Europejskiej konwencji państwa sygnatariusze podkreślają duże znaczenie sportu dla porozumienia międzynarodowego, zwłaszcza ze względu na częstotliwość meczów między europejskimi reprezentacjami i klubami. Ta kluczowa przesłanka idealnie wpisuje się w główny cel Rady Europy, jakim jest „osiągnięcie większej jedności między jej członkami, aby chronić i wcielać w życie ideały i zasady, stanowiące ich wspólne dziedzictwo, oraz aby ułatwić ich postęp ekonomiczny i społeczny"4. Należy także podkreślić, że $\mathrm{z}$ trzech głównych bloków działań Rady Europy, sprawy sportu, w tym i jego bezpieczeństwa, na stałe wpisały się do zagadnień związanych z demokracją.

2 Informacje na temat pożaru na stadionie Bradford pochodzą ze strony internetowej poświęconej temu wydarzeniu: http://bradfordcityfire.co.uk/, [21.08.2015].

3 Chapter 10: In conclusion, w: Ch. Rowland, From Where I Was Standing: A Liverpool Supporter's View of the Heysel Stadium Tragedy, GPRF Publishing, 2011, całość rozdziału dostępna na stronie internetowej: http://tomkinstimes.com/2013/05/heysel-25-years-on-book-extract/, [21.08.2015].

4 Art. 1 lit. a Statutu Rady Europy przyjętego w Londynie dnia 5 maja 1949 r., Dz.U. 1994 nr 118 poz. 565 . 
Europejska konwencja nie była tutaj pierwszym dokumentem, otworzyła jednak szerokie pole do współpracy międzynarodowej, powiązanej stricte z bezpieczeństwem kibiców. Co istotne mecze międzypaństwowe są w konwencji rozumiane jako zarówno pojedyncze mecze, jak i turnieje piłkarskie. Wyjaśnienia wymaga także ich pierwszeństwo względem innych wydarzeń sportowych. Mecze piłkarskie są bowiem uznane za najbardziej konfliktowe i niebezpieczne, przy równoczesnym wysokim społecznym zainteresowaniu. Stąd też regulacje dotyczą przede wszystkim tego typu aktywności sportowej, organizatorzy innego rodzaju imprez sportowych mogą jednak dostosować konwencyjne zapisy do swoich potrzeb (art. 1 ust. 2 EK). W tekście omawianego dokumentu zrezygnowano z wprowadzenia jakiejkolwiek definicji legalnej, w tym także dotyczącej międzynarodowego meczu piłki nożnej. Takie działanie dowodzi prymatu wewnętrznego ustawodawstwa państw sygnatariuszy, które w dowolnie wybrany sposób, zgodny z ich prawem, mogą kształtować wskazane w konwencji rozwiązania (art. 1 ust. 1 EK). Europejska konwencja kierowana jest przede wszystkim do państw: władz państwowych rozumianych jako organy rządowe i inne instytucje państwowe (w tym także siły policyjne) oraz do samodzielnych, narodowych organizacji sportowych. Obie te grupy ponoszą odrębną względem siebie odpowiedzialność za bezpieczeństwo meczów piłki nożnej. Powinny więc współpracować i uzupełniać się wzajemnie (Wstęp EK). Istotą Europejskiej konwencji jest jednak jej wartość dodana w postaci proponowanych środków działania. Nie zostały one szczegółowo omówione w tekście, stanowią jednak swoiste kamienie milowe na drodze do osiągnięcia zakładanego celu. Co ciekawe nie wymienia się ich z podziałem na kategorie czy obszary działań. Mamy tutaj do czynienia ze swoistą wyliczanką środków mogących wpłynąć pozytywnie na kwestie bezpieczeństwa kibiców. Stąd też obok dokładnie niesprecyzowanych działań sił porządkowych (aktywnych na stadionie i trasach dojazdowych kibiców) pojawia się współpraca i wymiana informacji między siłami policyjnymi czy propozycja nakładania kar lub środków administracyjnych wobec osób winnych popełnienia przestępstw wynikających z aktów przemocy lub wybryków widzów. Zauważalne są także echa tragedii stadionowych widoczne w zaleceniach zachęcających do dbałości o właściwą strukturę oraz rozplanowanie stadionów (w tym także w odniesieniu do materiałów użytych do budowy obiektu), oddzielenie sektorów dla zamiejscowych kibiców czy dążenie do wprowadzenia systemów informowania publiczności (art. 3 ust. 4 lit. a, b, e EK). Pojawiają się również, wciąż dyskutowane, kwestie alkoholu: konwencyjne zapisy zalecają zakazywanie wnoszenia tego typu napojów, a nawet ograniczenie bądź całkowite zabronienie ich sprzedaży na stadionach. Przymus sprzedaży w bezpiecznych (najczęściej plastykowych) opakowaniach, będący obecnie oczywistością, wtedy nie należał do ogólnie przyjętego standardu (art. 3 ust. 4 lit. f EK). Kontrowersyjną częścią Europejskiej konwencji są fragmenty niezgodne z ideą praw człowieka. Należą do nich: kwestie ciągłej kontroli kibiców (nawet w trakcie podróży na mecz), sprowadzające się często do ograniczenia prawa swobodnego 
przemieszczania się, współpracy sądowej (w tym ekstradycji) oraz wymiany informacji, tak między siłami policji, klubami piłkarskimi, jak i właściwymi władzami państwowymi. Jak zauważa Renata Kopczyk, Europejska konwencja dała podstawę normatywną do wprowadzenia do narodowych regulacji tzw. zakazu stadionowego. Wątpliwości dotyczą tutaj szerokiego zakresu działania tego środka oraz nadużywania sformułowania potencjalny w odniesieniu do osób, którym zasadniczo nie udowodniono sprzecznych z prawem działań, a jedynie przypisuje się im domniemane wrogie zamiary. Podsumowując wskazaną kwestię, warto odwołać się do cytatu zaczerpniętego z artykułu wskazanej wyżej autorki: „Jest to o tyle zdumiewające [wprowadzenie tzw. zakazów stadionowych - przyp. aut.], że organizacja, która ma na celu ochronę praw człowieka w sposób istotny przyczyniła się do ich ograniczania" [Kopczyk 2012]5.

Europejska konwencja uznaje współpracę międzynarodową za najlepszy sposób na poprawę bezpieczeństwa międzynarodowych imprez sportowych. Istotą zapisów nie są tutaj bowiem wyłącznie propozycje ogólnie zarysowanych rozwiązań - takowe pojawiły się już wcześniej w niektórych państwach sygnatariuszach konwencji. Clou stanowi wzajemna wymiana informacji i pomysłów, dzielenie się doświadczeniem i dojrzewanie do coraz skuteczniejszych rozwiązań. Stąd też za najbardziej doniosły efekt Europejskiej konwencji należy uznać powołanie Stałego Komitetu. Jego członkowie oraz, zaakceptowani przez sygnatariuszy, obserwatorzy spotykają się co najmniej raz w roku (art. 8 EK). Warto tutaj nadmienić, że w roli obserwatora występują m.in. UEFA (European Union Football Association) oraz FIFA (the Fédération Internationale de Football Association $)^{6}$. Do najistotniejszych zadań Stałego Komitetu należą: nadzorowanie stosowania Europejskiej konwencji oraz organizowanie spotkań grup ekspertów (art. $9 \mathrm{EK}$ ). Efektem prac wskazanego podmiotu jest szereg raportów oraz publikacji dotyczących m.in. bezpieczeństwa imprez sportowych, współpracy oraz wymiany informacji, prewencji, zwalczania rasizmu i nietolerancji, roli władz lokalnych i sił policyjnych w związku z organizacją meczów piłki nożnej Poszczególne państwa w ramach prac Komitetu realizują wizyty monitorujące oraz konsultacyjne, przygotowują narodowe profile.

5 R. Kopczyk, Prawo Unii Europejskiej wobec bezpieczeństwa meczu piłki nożnej, w: System bezpieczeństwa meczu piłki nożnej - krajowe aspekty prawne, organizacyjne, techniczne, socjologiczne, kryminologiczne, kulturowe i filozoficzne na tle wymagań międzynarodowych, Wolters Kluwer 2012 (praca przyjęta do druku), s. 8. Tekst artykułu dostępny pod linkiem: http://robertgrzeszczak.bio.wpia.uw.edu.pl/files/2015/03/BEZPIECZE\%C5\%83STWO-IMPREZ-MASOWYCH-W-\%C5\%9AWIETLE-PRZEPIS\%C3\%93W_R.-Kopczyk.pdf [26.08.2015].

6 Pełna lista obserwatorów Stałego Komitetu dostępna jest na stronie internetowej Rady Europy: http://www.coe.int/t/dg4/sport/violence/trvpc_en.asp, [26.08.2015]

7 Pełna lista wraz z treścią dokumentów dostępna jest na stronie internetowej: http://www. coe.int/t/dg4/sport/Resources/Ref_Text_Violence_en.asp\#TopOfPage, [24.08.2015]. 


\section{DECYZJA RADY Z 25 KWIETNIA 2002 ROKU ORAZ ZMIENIAJĄCA JĄ} DECYZJA RADY Z 12 CZERWCA 2007 ROKU

Decyzja Rady z 25 kwietnia 2002 roku, dotycząca bezpieczeństwa w związku $\mathrm{z}$ meczami piłki nożnej o charakterze międzynarodowym ${ }^{8}$, to jeden z nielicznych aktów prawnych mający charakter obligatoryjny ${ }^{9}$. Pozostawia on jednak wiele swobody państwom członkowskim w zakresie wyboru środków służących do osiągnięcia wskazanych celów. Uwzględniając różnorodność systemów prawnych oraz instytucjonalnych, każde państwo ma bowiem stworzyć własny system wymiany informacji używany w związku z zawodami oraz meczami piłki nożnej o charakterze międzynarodowym ${ }^{10}$. Zainteresowanie Unii Europejskiej wynika tutaj z globalnego charakteru piłki nożnej oraz coraz częściej rozgrywanych meczów międzynarodowych. Podobnie jak w przypadku deklaracji Rady Europy, daje się tutaj zauważyć jednoczącą rolę sportu i jej ogromny wpływ na europejskie społeczeństwa. Omawiana tematyka umiejscawiana jest w przestrzeni wolności, bezpieczeństwa i sprawiedliwości i dotyczy przede wszystkim współpracy policyjnej ${ }^{11}$. Nie wyłącza się jednak możliwości zaangażowania innych organów państwowych.

Decyzja Rady z 25 kwietnia 2002 roku już we Wstępie odwołuje się do Europejskiej konwencji oraz dorobku Rady Europy. W ten sposób zachowana zostaje swoista ciągłość. Podobnie jak było dotychczas, tak i tutaj brakuje definicji legalnej międzynarodowego meczu piłki nożnej. Zapisy zawarte w decyzji każą przypuszczać, że oprócz pojedynczych meczów rozgrywanych między narodowymi reprezentacjami bądź w ramach europejskich drużyn ligowych, należy brać pod uwagę także zawody sportowe, w tym i turnieje o mistrzostwo rozgrywające się w jednym bądź więcej państw ${ }^{12}$. Ponadto Decyzja Rady z 25 kwietnia 2002 roku odnosi się do podręcznika zaleceń dla międzynarodowej współpracy policyjnej z 2001 roku $^{13}$ oraz do podejmowanych wcześniej inicjatyw, w tym do rezolucji z 9 czerwca 1997 roku w sprawie przeciwdziałania i ograniczania chuligaństwa kibiców piłki nożnej poprzez politykę wymiany doświadczeń, wykluczanie ze stadionów oraz politykę medialną ${ }^{14}$.

Jedynym wymogiem, który wprowadza Decyzja Rady z 25 kwietnia 2002 roku, jest obowiązek wzajemnej wymiany informacji między państwami członkowskimi. Dokument koncentruje się tylko na tym aspekcie, pełniąc tym samym rolę swoistego uszczegółowienia Europejskiej konwencji w punkcie dotyczącym

${ }^{8}$ Dz. Urz. WE L 121 z 8 maja 2002 r., dalej jako decyzja Rady z 25 kwietnia 2002 r.

${ }^{9}$ Art. 288 Traktatu o funkcjonowaniu Unii Europejskiej.

${ }^{10}$ Wstęp do decyzji Rady z 25 kwietnia 2002 r.

${ }^{11}$ Pkt 1 Wstęp do decyzji Rady z 25 kwietnia 2002 r.

${ }^{12}$ Do tego typu turniejów można zaliczyć m.in. Mistrzostwa Europy w Piłce Nożnej.

${ }^{13}$ Obecnie obowiązujący podręcznik zaleceń został wprowadzony Rezolucją Rady UE $\mathrm{z}$ dnia 3 czerwca $2010 \mathrm{r}$.

${ }^{14}$ Dz. U. C 193. 
współpracy policyjnej. Istotę funkcjonowania narodowego punktu informacyjnego dla piłki nożnej sprowadza się do enigmatycznie zakreślonego bezpośredniego i centralnego charakteru umożliwiającego wymianę istotnych informacji i ułatwianie międzynarodowej współpracy ${ }^{15}$. Państwa same decydują o sposobie działania punktu i jego umiejscowieniu. Ponoszą także odpowiedzialność za wymiar prawny oraz dbałość o przestrzeganie istniejących przepisów prawa krajowego ${ }^{16}$. Decyzja Rady z 25 kwietnia 2002 roku przewiduje dwa zakresy tematyczne informacji. Pierwszy obejmuje dane osobowe kibiców tzw. wysokiego ryzyka, drugi - informacje ogólne dzielone na trzy kategorie, tj. strategiczne, operacyjne oraz taktyczne ${ }^{17}$. Ponadto pracownicy punktu przygotowują oceny ryzyka dotyczące klubów danego kraju oraz drużyny narodowej ${ }^{18}$. Informacje, którymi dysponują punkty, wymieniane są przed, w trakcie oraz po zakończeniu meczu na wniosek danego narodowego punktu informacyjnego bądź z własnej inicjatywy ${ }^{19}$. Te trzy etapy przygotowywane są na odrębnych formularzach, które po zakończeniu wydarzenia są archiwizowane. Na ich podstawie tworzone są raporty i noty informacyjne, które umieszcza się w specjalnie przygotowanym systemie informatycznym, wspólnym dla wszystkich państw członkowskich ${ }^{20}$. Kontakt między punktami realizowany jest przez oficera bądź oficerów łącznikowych ${ }^{21}$. Większość informacji przekazywana jest drogą elektroniczną przez specjalnie zaszyfrowany system wskazany wyżej, do którego dostęp mają wyłącznie upoważnione osoby. Stosowaną praktyką są także spotkania oficerów łącznikowych z różnych krajów, co wspomaga pracę policjantów przypisanych do danego narodowego punktu.

Decyzja Rady z 12 czerwca 2007 roku zmieniająca decyzję 2002/348/ WSiSW $^{22}$ wniosła do dotychczasowego unijnego dorobku zmiany związane z doprecyzowaniem zakresu tematycznego wymienianych informacji oraz procedur ich przekazywania ${ }^{23}$. Widoczne są tutaj doświadczenia pozyskane w trakcie organizacji mistrzostw Europy w 2004 roku oraz te zdobyte przez poszczególne narodowe punkty $\mathrm{w}$ trakcie ich pięcioletniego funkcjonowania ${ }^{24}$. Na drodze niniejszej nowelizacji unijny ustawodawca akcentuje potrzebę wprowadzenia uniwersalnych formularzy służących do wymiany informacji oraz konieczność umożliwienia państwom członkowskim dokonywania skutecznej oceny ryzyka. W pierwszym przypadku pomocą ma służyć dodatek do podręcznika zaleceń

${ }^{15}$ Art. 1 ust. 3 Decyzji Rady z 25 kwietnia 2002 r.

${ }^{16}$ Art. 1 ust. 5 Decyzji Rady z 25 kwietnia 2002 r.

${ }^{17}$ Art. 3 ust. 2 Decyzji Rady z 25 kwietnia 2002 r.

${ }^{18}$ Art. 2 ust. 5 Decyzji Rady z 25 kwietnia 2002 r.

${ }^{19}$ Art. 3 ust. 1 Decyzji Rady z 25 kwietnia 2002 r.

${ }^{20}$ Informacja pozyskana w trakcie rozmów z pracownikami brytyjskiego punktu informacyjnego dla piłki nożnej z dnia 08.09.2015 r.

${ }^{21}$ Art. 4 ust. 2 decyzji Rady z 25 kwietnia 2002 r.

22 Dz. Urz. WE L 155, dalej jako decyzja Rady z 12 czerwca 2007 r.

${ }^{23}$ Pkt 2, Wstęp do decyzji Rady z 12 czerwca 2007 r.

${ }^{24}$ Pkt 3, Wstęp do decyzji Rady z 12 czerwca 2007 r. 
w zakresie międzynarodowej współpracy policyjnej ${ }^{25}$. Kwestie ryzyka zostały ujęte tutaj dwojako. $Z$ jednej strony poszerzono materiał podlegający wymianie o regularne, ogólne lub tematyczne oceny krajowych zakłóceń porządku związanych z piłką nożną ${ }^{26}$. $Z$ drugiej zaś strony zmieniono art. 2 ust. 2 decyzji Rady z 25 kwietnia 2002 roku dotyczący dostępu przez narodowe punkty do informacji obejmującej dane osobowe kibiców ${ }^{27}$. Pierwotnie były to dane osobowe kibiców wysokiego ryzyka, co zostało zmienione na dane osobowe kibiców stanowiących ryzyko. Ta zdawałaby się subtelna zmiana umożliwiła poszerzenie grupy osób, których dane mogą być przekazywane między narodowymi punktami. Już nie muszą to być jednostki (bądź grupy) generujące wysokie ryzyko; wystarczy, że zostaną uznane za potencjalnie je stanowiące i niekoniecznie tak silnie zintensyfikowane, by przypisać im status wysokiego ryzyka. Widać więc tutaj wyraźne zmniejszenie ciężaru dowodowego na rzecz potencjalnego wpływu na bezpieczeństwo międzynarodowego meczu piłki nożnej.

\section{PODRĘCZNIKI WSPÓŁPRACY POLICYJNEJ}

Oprócz wskazanych wyżej dwóch obligatoryjnych aktów prawa unijnego, warto zwrócić uwagę na podręczniki odnoszące się do współpracy policyjnej między państwami członkowskimi. Pierwszy tego typu dokument wprowadziła rezolucja Rady z 21 czerwca 1999 roku $^{28}$. Nie funkcjonowały wtedy narodowe punkty informacyjne dla piłki nożnej, państwa musiały więc tworzyć własne struktury. Idea opublikowania podręcznika z zaleceniami miała prawdopodobnie ułatwić wzajemne przekazywanie dobrych praktyk i ujednolicenie wymienianych materiałów. Stąd też pierwszy podręcznik należy uznać za przełomowy, stanowi on ponadto wartość historyczną obrazującą ewolucję postrzegania bezpieczeństwa masowych imprez sportowych. Podręcznik, jak wskazuje rezolucja Rady, stanowi zestaw przykładowych metod pracy, możliwych do zaimplementowania przez siły policyjne dowolnego kraju ${ }^{29}$.

Treści zawarte w podręczniku z 21 czerwca 1999 roku odnoszą się do sześciu obszarów działań sił policyjnych, tj. przygotowania, organizacji wzajemnej współpracy, zarządzania informacją, współpracy ze stewardami, polityki medialnej i strategii komunikacji, wymagań dotyczących polityki wstępu i sprzedaży

${ }^{25}$ Dodatek stanowi załącznik do podręcznika zaleceń wprowadzonego na drodze rezolucji Rady z 6 grudnia 2001 r., Dz. Urz. WE C 22, dalej jako podręcznik z 6 grudnia 2001 r.

${ }^{26}$ Art. 1 pkt 1 b decyzji Rady z 12 czerwca 2007 r.

${ }^{27}$ Art. 1 pkt 1a decyzji Rady z 12 czerwca 2007 r.

${ }^{28}$ Council Resolution of 21 June 1999 concerning a handbook for international police cooperation and measures to prevent and control violence and disturbances in connection with international football matches, Dz. U. C 196, dalej jako podręcznik z 21 czerwca 1999 r.

${ }^{29}$ Tamże, pkt 1. 
biletów ${ }^{30}$. Jak podkreśla podręcznik, celami międzynarodowej współpracy policyjnej są przede wszystkim: gromadzenie informacji, w tym i tych o charakterze wywiadowczym, kontrola thumu oraz spotting ${ }^{31}$. Ostatnie określenie pochodzi z języka angielskiego i w wymiarze policyjnym oznacza obserwację thumu, skoncentrowaną na odnotowywaniu zachowań sprzecznych z prawem oraz na wyszukiwaniu osób, których uczestnictwo w danym wydarzeniu lub obecność w danym miejscu są zakazane. Podręcznik z 21 czerwca 1999 roku wyróżnia się przede wszystkim innowacyjnością (jak na ówczesne czasy) oraz kompleksowym podejściem do kwestii bezpieczeństwa. Omówienie zasad pracy oficerów łącznikowych czy polityka sprzedaży biletów i dostępu do stadionu stanowią cenną wartość dodaną do doświadczeń poszczególnych krajów. Należy jednak podkreślić, iż widoczna już tutaj ewolucja rozwiązań nie miałaby miejsca bez kolejnych wydań podręcznika, wzbogacanych nowymi doświadczeniami uzyskanymi w trakcie mistrzostw świata i Europy.

Następny w kolejności podręcznik powstał dwa lata później i został wprowadzony na drodze rezolucji Rady z 6 grudnia 2001 roku $^{32}$. Pierwszą zauważalną zmianą jest już sama nazwa podręcznika, do której dodano słowo „rekomendacje” (podręcznik z rekomendacjami). Podkreślono w ten sposób fakultatywny wymiar dokumentu i jego doradczy charakter. Także w zakresie definicyjnym nastąpiła zamiana - zamiast międzynarodowych meczów piłki nożnej, pojawiają się mecze piłki nożnej o wymiarze międzynarodowym. Poszerzono więc możliwość uznawania meczów wewnątrzpaństwowych za takie, które wymagają szczególnego zaangażowania. Zawężono natomiast możliwość wdrażania dokumentu do sytuacji, w których co najmniej jedno państwo członkowskie jest zaangażowane ${ }^{33}$. W podręczniku z 6 grudnia 2001 roku już we wstępie zaznaczono, iż jest on docelowo przeznaczony dla meczów piłki nożnej, co jednak nie wyklucza jego stosowania w innych międzynarodowych wydarzeniach sportowych. Ponadto, w porównaniu do poprzedniej wersji, dołączono przykładowe metody pracy dostępne dla sił policyjnych; położono także nacisk przede wszystkim na zarządzanie informacjami (podział informacji na ogólne i osobowe) oraz organizację sił policyjnych ${ }^{34}$.

Analiza treści znajdujących się w podręczniku z 6 grudnia 2001 roku daje zarys europejskiego systemu wymiany informacji między narodowymi punktami.

${ }^{30}$ Contents of the handbook, podręcznik z 21 czerwca $1999 \mathrm{r}$.

31 Słowo spotting jest formą czasownika spot występującą w funkcji rzeczownika. Angielskie spot oznacza zauważenie/dostrzeżenie kogoś lub czegoś. Por. hasło: spot, w: internetowym wydaniu Macmillan Dictionary: http://www.macmillandictionary.com/dictionary/british/spot_2, [29.08.2015].

${ }^{32}$ Council Resolution of 6 December 2001 concerning a handbook with recommendations for international police cooperation and measures to prevent and control violence and disturbances in connection with football matches with an international dimension, in which at least one Member State is involved, Dz. U. C 22, dalej jako: podręcznik z 6 grudnia $2001 \mathrm{r}$.

${ }^{33}$ Por. Tytuł podręcznika z 21 czerwca 1999 r. oraz z 6 grudnia $2001 \mathrm{r}$.

${ }^{34}$ Contents of the handbook, podręcznik z 6 grudnia $2001 \mathrm{r}$. 
Nowością są także pierwsze tego typu rekomendacje dotyczące roli organizatora oraz prawnych ujęć jego statusu (osoba prawna lub fizyczna, która organizuje lub instruuje osobę odnośnie do organizacji, w całości lub w części, narodowy lub międzynarodowy mecz piłki nożnej, z inicjatywy własnej bądź osoby trze$\left.c{ }^{35}{ }^{35}\right)$. Integralną częścią podręcznika są dwa załączniki odzwierciedlające treści zawarte w poszczególnych obszarach tematycznych. Stanowią one przykładową formę wdrażania i sprawdzania przedsięwziętych działań, mających w głównej mierze charakter policyjny. Pierwszym załącznikiem jest formularz zawierający strategiczne informacje dotyczące meczów piłki nożnej o wymiarze międzynarodowym. Drugi to lista obejmująca ewentualne wymagania stawiane organizatorowi. Obok nowych kwestii, takich jak m.in. spotkanie z kierownikiem ds. bezpieczeństwa czy standardy bezpieczeństwa w zakresie infrastruktury, pojawia się polityka sprzedaży i kontroli biletów - szeroko komentowana w podręczniku z 21 czerwca 1999 roku $^{36}$.

Rezolucja Rady z 4 grudnia 2006 roku $^{37}$ wprowadza kolejny podręcznik stanowiący szczególny drogowskaz dla narodowych punktów, funkcjonujących już wtedy na zasadzie obligatoryjności. Od roku 2002 punkty na drodze decyzji Rady z 25 kwietnia 2002 roku muszą powstawać bowiem w każdym państwie członkowskim. Nadal jednak funkcjonują one według zaleceń i rozwiązań przede wszystkim krajowych. Status podręcznika nie ulega więc zmianie, po raz kolejny treści w nim zawarte mają prowadzić do wzmocnienia współpracy policyjnej na zasadzie dobrowolności i dzielenia się dobrymi praktykami. Wprowadzono także w pełni nowy element, jakim jest potrzeba współpracy ekspertów na poziomie dyskusji ogólnoeuropejskiej, uwzględnianej w ramach spotkań realizowanych w trakcie każdej prezydencji.

Podręcznik z 4 grudnia 2006 roku wprowadza także niespotykaną dotąd specyfikację działań policyjnych oraz elementów im towarzyszących. Na potrzeby efektywnej wymiany informacji upraszcza stosowaną dotąd kategoryzację kibiców piłki nożnej. Zamiast dotychczasowej, niejednoznacznej trójstopniowej skali (A, B, C; gdzie A to kibic nie- stwarzający zagrożenia, a B i C to stopniowalne poziomy kibiców stwarzających zagrożenie) wprowadza się dwubiegunowy podział na kibiców niestwarzających bądź stwarzających zagrożenie. Pomocna przy charakteryzowaniu kibiców stwarzających zagrożenia ma być lista kontrolna w postaci formularza, zawierająca takie elementy jak m.in. zakłócenia porządku publicznego czy działalność przestępcza ${ }^{38}$. Oprócz powyższego, załączniki do

${ }^{35}$ Definicja organizatora, w: rozdział 6, podręcznik z 6 grudnia $2001 \mathrm{r}$.

${ }^{36}$ Załączniki do podręcznika z 6 grudnia 2001 r., s. 13-25.

${ }^{37}$ Rezolucja Rady z dnia 4 grudnia 2006 r. w sprawie zaktualizowanego podręcznika zaleceń w zakresie międzynarodowej współpracy policyjnej oraz w zakresie działań prewencyjnych i kontrolnych związanych z aktami przemocy i zakłóceniami porządku podczas międzynarodowych meczów piłki nożnej, które dotyczą co najmniej jednego państwa członkowskiego, Dz. U. C 322, dalej jako: podręcznik z 4 grudnia 2006 r.

${ }^{38}$ Załącznik 1 do podręcznika z 4 grudnia 2006 r., s. 19. 
podręcznika z 4 grudnia 2006 roku zawierają formularze wymiany informacji realizowane $w$ ramach ogólnie przyjętej procedury oraz uzupełniają i aktualizują treści zaanonsowane w podręczniku z 6 grudnia 2001 roku dotyczące ewentualnych wymogów, które powinien spełniać organizator. Wyjątkowy charakter ma ostatni, czwarty dodatek określający wygląd policyjnych kamizelek identyfikacyjnych wraz z załączonymi przykładowymi zdjęciami ${ }^{39}$.

Obecnie obowiązujący podręcznik został wprowadzony rezolucją Rady z 3 czerwca $2010 \mathrm{roku}^{40}$. Prezentuje on nowoczesne ujęcie kwestii bezpieczeństwa akcentujące wieloaspektową i wielopodmiotową wymianę informacji. Zmianie uległa większość rozwijanych dotychczas obszarów tematycznych, zostały one inaczej skatalogowane - wybija się tutaj idea odnoszenia współpracy policyjnej do kluczowych podmiotów dla bezpieczeństwa meczów piłki nożnej. Punktami, które w podręczniku z 3 czerwca 2010 roku nie uległy zmianie, są: zarządzanie informacjami przez policję oraz spotkania unijnych ekspertów ${ }^{41}$. Powraca także odrębna pula zagadnień dotyczących strategii komunikacyjnej i medialnej.

Swoiste novum w zakresie zarządzania informacjami stanowi wzbogacenie źródeł informacji narodowych punktów o policyjne bazy danych. Specyfikacji podlega procedura komunikacji między narodowymi punktami państwa organizującego a państwa wspierającego. Po raz pierwszy w kontekście bezpieczeństwa pojawia się Europol i jego oficer łącznikowy (ELO) ${ }^{42}$. Ponadto podręcznik proponuje kooperację policji z inicjatywami kibicowskimi, takimi jak stowarzyszenia czy ambasady kibiców ${ }^{43}$. Warto podkreślić, że te ostatnie cieszyły się popularnością szczególnie w trakcie mistrzostw Europy w Austrii i Szwajcarii w 2008 roku oraz w Polsce i na Ukrainie w 2012.

Najnowsza wersja podręcznika przewiduje cztery dodatki, z których dwa stanowią aktualizację dodatków pochodzących z podręcznika z 4 grudnia 2006 roku. Są to: specyfikacja policyjnych kamizelek oraz kategorie kibiców piłki nożnej. Nowością, wynikającą z zaangażowania Europolu, jest formularz terminów realizacji zamówień dotyczących produktów i usług świadczonych przez agencję. Kolejny dodatek pojawiający się pierwszy raz to dynamiczna ocena ryzyka oraz zarządzanie tłumem, wzbogacone o modele rozwiązań sprawdzone w krajach członkowskich.

Przeanalizowany powyżej podręcznik utrwalił w dorobku unijnym doświadczenia i dobre praktyki państw Wspólnoty. Nowe propozycje przeplatają się tutaj z wciąż udoskonalanymi rozwiązaniami znanymi z podręcznika z 21 czerwca

39 Załącznik 4 do podręcznika z 4 grudnia 2006 r., s. 39.

${ }^{40}$ Rezolucja Rady, z dnia 3 czerwca 2010 r., w sprawie zaktualizowanego podręcznika z zaleceniami w zakresie międzynarodowej współpracy policyjnej oraz w zakresie działań prewencyjnych i kontrolnych związanych z aktami przemocy i zakłóceniami porządku podczas międzynarodowych meczów piłki nożnej, które dotyczą co najmniej jednego państwa członkowskiego, Dz. U. C 165, dalej jako podręcznik z 3 czerwca $2010 \mathrm{r}$.

${ }^{41}$ Dodano tylko frazę: $z$ dziedziny piłki nożnej.

${ }^{42}$ Rozdział 1, podręcznik z 3 czerwca $2010 \mathrm{r}$.

${ }^{43}$ Rozdział 6, podręcznik z 3 czerwca $2010 \mathrm{r}$. 
1999 roku. Za niekwestionowaną zaletę obecnie obowiązującej wersji należy uznać klarowne rozdzielenie wątków i ułożenie ich w logiczną całość. Także skoncentrowanie się na siłach policyjnych i narodowych punktach informacyjnych dla piłki nożnej (NFIP) jako podmiotach aktywnych zasługuje na uwagę. Działalność narodowych punktów opiera się bowiem na aktywności sił policyjnych, a nie na sposobie funkcjonowania innych podmiotów, takich jak np. organizator czy kibice. Są oni ważni w odniesieniu do meczów piłki nożnej, jednak to nie oni mają pełnić rolę centrum wymiany informacji o charakterze poufnym i ściśle powiązanym $\mathrm{z}$ bezpieczeństwem i porządkiem publicznym.

\section{PODSUMOWANIE}

Opisany i przeanalizowany powyżej dorobek Unii Europejskiej w zakresie współpracy sił policyjnych krajów członkowskich oraz wymiany informacji między nimi nie wyczerpuje w pełni tej tematyki. Dokładne jej opracowanie przekraczałoby rozmiary niniejszej pracy kilkakrotnie. Dobór dokumentów bazował więc na ich wpływie na państwa UE i na stan debaty na temat bezpieczeństwa międzynarodowych meczów piłki nożnej. Starannie zinterpretowana Europejska konwencja otwiera niejako unijne regulacje, stając się pierwszym przewodnikiem, swoistym wzorcem i inspiracją. Kolejne dokumenty, tj. decyzja Rady z 25 kwietnia 2002 roku i jej nowelizacja, oraz cztery wydania podręcznika można uznać za udaną egzemplifikację woli europejskich państw i ich dążeń do efektywnej współpracy, pozbawionej narzucanych odgórnie rozwiązań.

Pytanie dotyczące fakultatywności podejmowanych rozwiązań, zadane we wstępie, należy rozpatrywać dwutorowo. Po pierwsze, za dobrowolną formą przyjmowania rekomendacji przemawia ich niesprecyzowany charakter. Treści zawarte w podręcznikach proponują bowiem pewne gotowe rozwiązania, których wykonanie pozostawia się regulacjom krajowym. To państwa mają decydować, w jakie uprawnienia wyposażą swoje siły policyjne oraz jak będą kształtować współpracę z organizatorami, kibicami, podmiotami zewnętrznymi i wewnętrznymi zaangażowanymi w organizację międzynarodowych meczów piłki nożnej. Takie podejście sprzyja otwartości i dyskusji, pozostawia wiele przestrzeni pomagającej rozwijać się państwom w dogodnym dla nich czasie i stopniu intensywności. Po drugie, należy pamiętać, iż regulowana tematyka dotyczy tak wrażliwej strefy działalności państw, jak dzielenie się informacjami zdobytymi przez siły policyjne, mającymi często status poufnych.

Nie należy jednak zapominać, iż fakultatywny wymiar współpracy może działać na państwa na zasadzie blokady, hamującej rozwój, a tym samym nienadążającej za dynamicznie zmieniającymi się zagrożeniami. Dowolne kształtowanie dokumentacji wymienianej między narodowymi punktami znacznie utrudnia pracę oficerów łącznikowych. Ze zdobytych informacji z brytyjskiego narodowego punktu wynika, że pojawiają się często problemy w komunikacji, związa- 
ne z niedostosowaniem wysyłanych materiałów do zawartych w podręcznikach formularzy. Siły policyjne wybiórczo decydują się na proponowane rozwiązania, co utrudnia współpracę i tworzy bariery między zespołami policyjnymi z różnych państw. Także brak spójności definicyjnej utrudnia klasyfikowanie i aktualizowanie informacji przepływających pomiędzy narodowymi punktami. Warte podkreślenia jest obligatoryjne przyjęcie decyzji Rady z 25 kwietnia 2002 roku wprowadzające obowiązek utworzenia narodowych punktów informacyjnych dla piłki nożnej (NFIP), mimo że istniały one już wcześniej w niektórych państwach członkowskich. Unijny ustawodawca uznał jednak ich priorytetowy charakter i włączył je w struktury sił policyjnych krajów członkowskich. W kontekście sprawnie realizowanych międzynarodowych meczów i turniejów piłki nożnej należy uznać ten krok za milowy w analizowanym obszarze. Bez niego współpraca policyjna nie byłaby tak efektywna i zakrojona na międzynarodową skalę.

\section{WYKAZ PIŚMIENNICTWA}

\section{AKTY PRAWNE:}

1. Council Resolution of 6 December 2001 concerning a handbook with recommendations for international police cooperation and measures to prevent and control violence and disturbances in connection with football matches with an international dimension, in which at least one Member State is involved, Dz. U. C 22.

2. Council Resolution of 21 June 1999 concerning a handbook for international police cooperation and measures to prevent and control violence and disturbances in connection with international football matches, Dz. U. C 196.

3. Decyzja Rady z dnia 12 czerwca 2007 r. zmieniająca decyzję 2002/348/WsiSW, Dz. Urz. WE L 155.

4. Decyzja Rady z dnia 25 kwietnia 2002 r. dotycząca bezpieczeństwa w związku z meczami piłki nożnej o charakterze międzynarodowym, Dz. Urz. WE L 121.

5. Europejska konwencja w sprawie przemocy i ekscesów widzów w czasie imprez sportowych, a w szczególności meczów piłki nożnej, sporządzona w Strasburgu dnia 19 sierpnia 1985 r., Dz.U. 1995 nr 129 poz. 625.

6. Rezolucja Rady, z dnia 3 czerwca 2010 r., w sprawie zaktualizowanego podręcznika z zaleceniami w zakresie międzynarodowej współpracy policyjnej oraz w zakresie działań prewencyjnych i kontrolnych związanych z aktami przemocy i zakłóceniami porządku podczas międzynarodowych meczów piłki nożnej, które dotyczą co najmniej jednego państwa członkowskiego, Dz. U. C 165 .

7. Rezolucja Rady z dnia 4 grudnia 2006 r. w sprawie zaktualizowanego podręcznika zaleceń w zakresie międzynarodowej współpracy policyjnej oraz w zakresie działań prewencyjnych i kontrolnych związanych z aktami przemocy i zakłóceniami porządku podczas międzynarodowych meczów piłki nożnej, które dotyczą co najmniej jednego państwa członkowskiego, Dz. U. C 322.

8. Statut Rady Europy przyjęty w Londynie dnia 5 maja 1949 r., Dz.U. 1994 nr 118 poz. 565.

9. Traktat o funkcjonowaniu Unii Europejskiej - tekst skonsolidowany uwzględniający zmiany wprowadzone Traktatem z Lizbony, Dz.U.2004.90.864/2. 


\title{
PUBLIKACJE:
}

1. Kopczyk R., 2012: Prawo Unii Europejskiej wobec bezpieczeństwa meczu piłki nożnej. W: System bezpieczeństwa meczu piłki nożnej - krajowe aspekty prawne, organizacyjne, techniczne, socjologiczne, kryminologiczne, kulturowe i filozoficzne na tle wymagań międzynarodowych. Wolters Kluwer (praca przyjęta do druku), 8.

2. Rowland Ch., 2011. From Where I Was Standing: A Liverpool Supporter's View of the Heysel Stadium Tragedy. GPRF Publishing.

\section{ŹRÓDŁA INTERNETOWE:}

1. http://bradfordcityfire.co.uk/

2. http://www.coe.int/t/dg4/sport/ Resources/Ref_Text_Violence_en.asp\#TopOfPage

3. http://www.coe.int/t/dg4/sport/violence/trvpc_en.asp

4. http://www.macmillandictionary.com

\section{THE EU'S INVOLVEMENT IN ENSURING SAFETY AND SECURITY OF INTERNATIONAL FOOTBALL MATCHES: POLICE COOPERATION AND EXCHANGE OF INFORMATION}

\begin{abstract}
The aim of this paper is to describe and analyse police cooperation and the exchange of information between National Football Information Points (NFIPs) to ensure safety and security at international football matches. The author assesses the choice between the obligatory and optional nature of regulations in this area. Attention is also focused on the evolution of the topics and solutions connected with public order and the safety and security of football matches.
\end{abstract}

Key words: safety and security of football matches, handbooks of international police cooperation, international police forces cooperation, National Football Information Points, European Convention on Spectator Violence and Misbehaviour at Sports Events and in particular at Football Matches 